\title{
Or.
}

ISSN 2278 - 0211 (Online)

\section{The Areas of Contention in Nigerian Politics, Restructuring, Economy and Challenges of Democracy}

\author{
Jibrin Ubale Yahaya \\ Part Time Lecturer, Department of Political Science, National Open University of Nigeria, Nigeria
}

\begin{abstract}
:
Restructuring in Nigerian politics has long been an issue of contentious debate where various scholars, politicians and Human Right activist argue that federalism promote disunity since Nigeria has different categories of ethnic and religious group with different norms and values, where in the other side some blame the current federalism system as blocking access to economic development because the central government dominate the national economy living the resourceful communities in poverty, hunger and unemployment while the other side of argument believe that federalism promote national integration because the central government has the power on basic national issues like security, national economy regulations and foreign policy operations that sustain the country existence while some power was devaluated to various units of governments at State and Local Government. This paper does not intend to examine the various causes of Nigerian political, economic and social problems but to look at some of the contemporary issues that are threat to Nigerian democracy and suggest possible measures to address it.
\end{abstract}

Keywords: Federalism, re-structuring, development challenges, good governance

\section{Introduction}

It's important at this junction to ask question that how can a nation -state adopt the federal system of governance and at the same time, the constitutional provision that has given life to that system from 1979 to date where peoples from different zones and tribes asked for structuring the nature of how government operates in Nigeria. The problem with Nigerian democracy of today was clipped up with marginalization of some regions or zone this makes them feel to be separated because of injustice suffered in the process of running affairs of governance of a given country which calls for restructuring the mode of governance operations (Adibe,2016)

According to Nuhu (2016), has a view that" restructure" is not independently defined in the dictionary. But as prefixed word, the concept can be defining as a process, the case of a nation-state that requires it citizens to take a close look at national edifice. The issue of restructuring in Nigeria needs to be observe from historical perspective by looking at the structures of government since independence in a multi-ethnic society and secondly, the constitutional provisions undergirding the structure.

Democracy is a kind of popular form of government in the world today; there is hardly any leader who does not wish to be seen as a democrat or a regime that does not seek to be described as democratic in nature. Democracy also holds a strong appeal among the ordinary people. In the last decade, the world has witnessed the emergence of mass organization in Africa, Asia and Eastern Europe that have risen to demand an end to dictatorial rule and its replacement with democracy.

Politics has been perceived by various scholars as an art of government or what concern about the state, conduct and management of public affairs, the resolution of conflict through discussion, bargaining, compromise and the conduct of power distribution, allocation of resources between various units of governments in the country (Akinyemi, 2005).

The phrase "government of the people" refers to the concept of direct democracy. In this system, people will actively involved themselves in public affairs and rule themselves. There are no differences between rulers and ruled. This paper will analyze Nigerian contemporary political process connotations of democratic practice and proper solution on how to address emerging problems for better nation building and development in Nigeria.

This paper does not intend to examine the various causes of Nigerian political, economic and social problem but to unravel the origins of these problems and suggest policy measures aimed at addressing these problems. 


\section{Conceptual Framework}

\subsection{Restructuring of Institutions in Nigeria}

Restructuring is a process to change the way in which government conduct business of public affairs. Restructuring does not mean the merging of states, as some people would think. Rather, it is a process people envisaged, that could allow each region to control its natural mineral and human resources and pay royalties to the central government. Nwanko (2016) view structuring "as a process which claims anchored on the principle of aspiring for people's needs that help us to stem the tide of restiveness in many parts of the country. It will also resolve the questions of citizenship, religion, resource control and fiscal federalism."

Many scholars, politicians and other pressure groups advocate for restructuring in Nigeria with no fewer than two political grounds. First, it was argued that this type of federalism system operated in Nigeria promote disunity since the different ethnic groups in the country has different norms and values. Secondly, it was argued that present federalism system in Nigeria did not promote economic development because central government dominate the economy while those who produce the economy are deprived living in hunger and abject poverty while the money is going to the pocket of few individuals.

In an attempt to provide a truly altruistic view of structuring, Ihonvbere (2002) argue thus:

What has become power sharing in the context of Nigerian federalism would normally be a good political agenda designed, religious and cultural groups an almost equal opportunity to manage the affairs of the nation. But in the Nigerian context the issue needs to be very cautious if we are to understand the driving forces behind the strident calls for power sharing that has become a national obsession. The truth of the matter is that Nigerian politicians have been calling or new pattern of power sharing not because they are genuinely interested in gaining a share of power in the interest of their respective nationality, religious or interest groups, but because they see such arrangement as an easy route to grab power and deploy it for primitive private capital accumulation.

However, the question that is yet to be addressed in a country where those few control the levers of power, both within the public and private sectors have been over empowered at the disadvantage of majority, how will this few minority controlling sources of power will allowed any kind of restructuring (change) to take place for the benefit of poor majority.

Lending his voice for the call for structuring Nigeria, Former Vice President, Atiku Abubakar (2016) choose to say," our current structure and practices it has encourage a major impediment to the economic and political development of our country, in short, it has not served Nigeria well, and at risk of reproach it has not served any part of the country, the North as well. The call for structuring is even more relevant today in light of the governance and economic challenges facing us as well as rising tiding of agitations, some militant and violent, requires a reset in our relationship as a united nation."

The extent of the power centralization in Nigeria can be measured from four perspectives mainly political, institutional, economic and financial. According to Oluwa (1955), centralization in the political science donates the absence of competitive and political structure where the yearning and aspiration of people are not meet because the key power is not with them.

Many arguments has been raised with central issue of restructuring which aimed to promote development that claims our current structure has facilitate the emergence of ethnic and regional inequalities and conflict between various groups in the country. The failure of restructuring to excessive focus on state structures as the agent of development to the neglect of popular view and interest of the public. Secondly, the centralized stove system encouraged the expansion of the state bureaucracies beyond available skills. Thirdly, the centralization led to much corruption since it stifled mechanisms for ensuring accountability on the part of public officials.

In the wake of widespread disappointment with the centralized state structure and, as part of the ongoing democratization process, the transfer of some power and resources from the central to local units' level of governments and organizations has meet the desire of many Nigerians that is why structuring has been advocated by different groups to have a change in the way of running affairs of governance in Nigeria.

To many donor agencies and international financial institutions such as World Bank, restructuring is seen as a means of creating an enabling environment for development and promoting accountability. For most African countries, the restructuring is now viewed as a strategy for mobilizing local resources and initiative for national development. It is also hoped that granting a measure of autonomy and thereby a level of self-determination to local groups through restructuring would advance the commitment to national stability and enhance state legitimacy. On the part of the broad mass of the people, restructuring is seen as an important aspect of democratization and a means whereby people are allowed to offer their role in the management of their own affairs.

\section{Political Economy and Nigeria's Economic Crisis}

Nigerian economy was in crisis, because what is generally agreed upon is the explanation of the causes of this economy crisis and solutions to it. Some have blamed the crises on the disarticulated nature of the economy, others blamed it on military rule which lacks public accountability and is enshrined in the passions for primitive capital accumulation, others have blamed it on the blocked capitalist ideology, yet others blamed it on the corrupt practices of those at the helm of affairs while others have explained it in terms of the present global recession which is manifestation in Nigeria as a dependent or satellite state. 
The current economic crisis started in the early 1980s. This does not means between 1960 and 1981 as Nigeria did not witness economic problems or acquired debts. Indeed, the economic strategies of "transfer of technology" and import substitution industrialization "which were rooted after independence did not address the structural problems and contradictions of the Nigerian economy and served to predispose Nigerian to foreign borrowing or loans. The crisis of the 180s was occasioned by the fall in the price of oil in the world market and worsened by the contradictions of a dependent accumulation pattern and a preponderantly mono-cultural economy based on rents from oil.

Nigerian economy is characterized by lack of organic linkages between agriculture and industry, production and consumption, an autochthons capital base, development of indigenous manufacturing sector, balance of payment problem, heavy debt burden, low gross domestic product (GDP), labour inflexibility, high unemployment rate, inadequate provision of social services and poor maintenance of infrastructural facilities, the near collapse of manufacturing sector and many more. Others are clear manifestations as the Nigerian economy is a product of neo-colonial capitalist economy.

Nigerian economy today is not under the control of Nigerians with this reality, the Nigerian state cannot embark on policies that can fundamentally restructure the Nigerian economy for a proper development. This is because it is caught in the trappings of neo-colonial capitalist contradictions which have produced a distorted dominant capitalist class whose interest is not the development of an auto centric capitalist economy. This does not deny the fact of the existence of a genuinely aspiring capitalist class of Nigerians.

Olaitan (1995) has highlighted the organic relationship between the state and economy is the development process. Thus, for so long as the Nigerian economy is not in the firm control of Nigerians, the state cannot be independent to pursue developmental projects for the wellbeing of the masses.

Nnoli (1981:29) disserted development into the economic, social and political aspects. Economic development, according to him, is concerned primarily with growth in GDP, industrialization and capital formation. Social development emphasizes the institutionalization of western social norms and behavioral pattern while political development focuses on political stability and institutionalization of goals and means for achieving them. These three strands belong to the western model of development.

Nigeria as a county whose citizens are educationally cultivated but our education cannot mobilize the latent resources to achieve maximum output. In other aspects, society is also developed if resources are fairly distributed among its citizens, the economy is not vulnerable or unduly exposed to external forces, and its political system is stable.

\section{Problems and Challenges Of Democracy In Nigeria}

Democracy cannot be taken for granted; its form or contents, survival and growth depend on the collective will and commitment of the Nigerian society as a whole. Despite the numerous differences which exist among Nigerian society such as level of economic, social and political developments, territorial and population size and colonial experiences. There are nevertheless, some common problems that face democracy and democratization process in Nigeria. The politics of poverty fosters the formation of groups and classes with conflicting material interest, and this tends to divide synonymous protection of the minority interests and serve other goals. It invest each segment with the power of protecting itself, and placed the rights and safety of each where only they can be securely placed under his own guardianship. Without this, there can be no systematic, peaceful or effective resistance to the natural tendency of each to come into conflict with the other.

\subsection{Lack of Institutionalization}

The absence of effective political institution is one of the major problem in Nigerian politics. This has, in turn contributed to the inability of most African States to establish and sustain political order. S.P. Huntington (1981) argues that, unlike developed countries, most third world nations including Africa lacked "strong, adaptable and coherent political institutions". Worse still, virtually all African states have borrowed from foreign institutions to develop rather than earning for development as African states become slaves and promoters of Western Democracy.

The Nigerian political system deficiencies, lack of well organized political parties, inefficient bureaucracies, low degree popular participation in public affairs, ineffective structure of civilian control over the military, and absence of relatively effective procedure for regulating agitation of success like movement of independence of Biafra state. The implication of these systems and process deficiencies is the failure to create political order in Nigeria.

\subsection{Tribalism/ Ethnicity}

Tribalism and ethnicity is one of the dangerous legacies inherited from colonial rule. In Nigeria, tribalism has a negative connotation though there are ethnic groups in other parts of the world, who are equally or highly antagonistic as those in Africa, but their differences like the one between the Serbs and the Croats are attributed to religion, not tribe. Consequently, the relations between the Maasai and Kikuyi in Kenya, the Hutu and the Tutsi in Rwanda and Burundi, the Zulu and Xhosa in South Africa are perceived in competitive and sometimes acrimonious terms. But in Nigerian context since independence in 1960, was undivided on three major tribes of Hausa-Fulani, Yoruba, Igbo and other minority tribes.

So, the problem of democratic process in Nigeria is that every leader emerge from one particular tribe he give priority to the interest of his tribes not the agenda of nation building. 


\subsection{Corruption}

The issue of corruption in Nigerian context becomes one of the serious factors that bring about setback to democracy process in Nigeria. For instance, since the return of democracy in 1999, the issue of corruption has become a political disaster where few use the huge public resource in pocket for their own interest which leads to the presence contemporary level of higher number of unemployment and raising level of poverty.

\section{Conclusion}

Nigerian economy is distorted and within the strangle hold of Western capitalism, Nigerians can continue to experience crisis because we look to our solutions externally derived but address our economic crisis. Our leaders must be committed towards independent diversification of economy to exploit various sectors of economy.

The Nigerian political system process should provide leaders who are capable to empower and strengthen our institutions to work effectively free from corruption and bureaucracies, addressing the contention of tribalism and ethnicity. If Nigeria as country will address this issue, our political system can be a model in Africa for other countries in Africa to copy.

\section{Recommendations}

National integration as demonstrated by our history is a complex and varied development needed to united a people under a government and create among them a stable, cultural, economic, political and peaceful society in Nigeria. Despite the complexity of Nigerian society peoples with different values, culture and ethnic identities need to live with our difference but agree to live as one nation, as cited by Awolawo (1968) who observed that, the federalism imposed by the British colony was a 'paradoxical' and British legacy " abominable, disrupting and divisive'. But all this does not stop the Nigerian society to chart a way of running government which all inclusive carrying every tribes and ethnic groups in the country by ensuring open , transparent and accountable government that provide responsive and functional government that will meet the needs and aspirations of every Nigerians.

Secondarily, I share a view of Egwu (2002), who cited despite the strains and stress which Nigeria's federalism system suffer, since the intervention of military rules after the country independence that eroded our constitutional basis of federalism, but the major point of consensus among the political elites and point of view of many Nigeria's on the adaptation of operating the principles of federalism in Nigeria is a success point that will keep the survival of Nigeria despite our difference which are manifested in different part of the country as a threats to integration as in case of the past civil war between 1967-1970, still current agitation for Biafra State from South-East, Boko Haram attacks since 2009 and Fulani pastoralist and farmers conflict in Benue, Zamfara and Kaduna are issues of security threat calling for caution for the survival of Nigeria as one country one nation. However, our elected leaders in the position of power must show commitment and pay selfless service to nation by putting all effort to keep the country one.

\section{References}

i. Adibe, J. (2016), Nigeria @ 56? Is this Really Falling? Daily Trust, Newspaper, October 6, 2016, p.48

ii. Akiyemi, B. (2005) Africa in the World of $21^{\text {st }}$ Century. Ibadan University Press, Ibadan.

iii. Awolowo, O. (1947), Path to Nigerian Freedom. London: Faber print

iv. Ihonvbee.J. (2002) The Nigerian State as Obstacle to federalism: towards a new constitutional compact for democratic politics, in A.T Gana and S.G Egwu, eds., Federalism in Africa: The imperative of Democratic Governance, Vol. Two, Treton, N.J , African World Press, Inc, A publication of the African Centre for Democratic Governance, Abuja.

v. Egwu,S. andGana, I. (2002) The crisis of the Nation State in Africa and the Challenges of Federalism in Africa, African World Press,Inc, A publication of the African Centre forDemocratic Governance, Abuja.

vi. Nuhu, Y. (2016) What is in Restructuring in the Era of Change in Nigerian Politics. Contribution to the proceeding of IASTEM International Conference, Damnam, Saudi Arabia, 17th and 18 December, 2016.

vii. Nnoli, O. (1981), Path to Nigerian Development, Dakar, Codestria.

viii. Nwankwo, A.(2016) Being the Text of an interview titled "No Alternative to Restructuring in Nigeria", Granted to the Gurdian Newspaper, Sunday, August , 28,2016. Pp.16-17

ix. Oluwa. N. (1995) Democracy in Africa, the way Forward, Abuwa Print, lagos

x. Oatley, T. (2004). International Political Economy; New Delhi, Pearson Publication Ltd. 